\title{
Character Education Through Discussion Activities in STKIP PGRI Lubuklinggau Students
}

\author{
Agus Susilo, Yeni Asmara \\ History Education Study Program of STKIP PGRI Lubuklinggau \\ Agussusilo594@yahoo.co.id, yeni.stkip@gmail.com \\ ${ }^{*}$ Corresponding Author \\ Whatsapp number: [085609465469]
}

How to Cite : Susilo, A., Asmara, Y. (2020). Character Education Through Discussion Activities in STKIP PGRI Lubuklinggau Students. International Journal for Educational and Vocational Studies, 2 (1), 79-85. DOI: https://doi.org/10.29103/ijevs.v2i1.2008

\section{ARTICLE HISTORY}

Received: 13 October 2019

Revised: 22 December 2019

Accepted: 26 January 2020

\section{KEYWORDS}

Education;

Character;

Discussion:

Students;

\begin{abstract}
The current era of globalization makes humans very easy to reach an activity. Humans are basically creatures whose lives always undergo alternating phases. So in the current era of globalization, the world of education for the younger generation, especially students, requires character education that builds the nation's wisdom. Character education is through group study or discussion. The purpose of writing this research is to find out character education through discussion activities on STKIP PGRI Lubuklinggau students. The method used in this research is descriptive qualitative method, which uses observations, interviews, and literature studies to examine research studies. The results of the study note that innovative media in classroom learning in semester $V$ students of STKIP PGRI History Education in Lubuklinggau is very necessary and very helpful in learning. Innovative media applied by lecturers in learning turns out to be able to shape the character of students who were previously passive and feel bored with the learning taught by the lecturer. Students feel there is a responsibility in participating in learning and trying to leave their laziness in the classroom. In addition, character education through discussion activities for STKIP PGRI Lubuklinggau students is very helpful in learning to respond to something and foster a high morale and foster a spirit of empathy.
\end{abstract}

This is an open access article under the CC-BY-SA license.

\section{INTRODUCTION}

Lately we have been confronted with various problems of moral decline in the nation's children, and even more alarming that happened to school-age children. The less encouraging phenomena include the many student brawls, immoral relationships among students and students, pornography, drug abuse, theft and murder committed by people who are students (Hidayatullah, et al, 2017: 486). Building human character is not as easy as turning the palm of the hand. Exemplary is one of the appeals to be used in treading the life of a community so that without feeling the impact that appears very powerful.

In the midst of the rapid progress of science and technology, with all the positive and negative effects, the inevitability of future human beings who remain faithful and devoted on the one hand and on the other hand become intelligent, skilled, and independent human beings and able to compete with others is an obsession and ideals that can not be negotiable. Therefore, future generations must be prepared to be able to survive, compete and have quality and qualified in certain fields. If not, they will be co-opted by the currents of globalization and modernization (Jalil, 2012: 176).

The implementation of education consisting of educators and education staff has the responsibility to apply the ideas and concepts of education in shaping the character of students in schools. This requires a struggle that is tenacious, committed, hard work, and consistent so that it can be realized properly. Based on this description, it is considered feasible to conduct research by focusing on the implementation of character education in learning in the world of education. This study seeks to explore the implementation of character education in learning, and also to reveal various supporting and inhibiting factors in the implementation of character education in learning so that it can be used as input or suggestions for schools to develop the potential possessed in the development of curriculum and learning (Wiliandani, et al, 2016: 133). 
The learning process, in addition to aiming to make students master competencies, is also designed to make students recognize, realize, care and also internalize the values of character education and then apply it in daily behavior. The use of appropriate media is one of the main factors in creating an effective learning atmosphere. Therefore, the use of media in learning will be beneficial for students in receiving messages and for teachers in conveying messages so that learning objectives will actually be achieved (Prasetya, 2017: 56).

Education is an effort to develop cognitive, affective, and psychomotor domains. Cognitive domains are the growth and development of intelligence and academic intellectual abilities, affective domains lead to the formation of personality traits, and psychomotoric domains will lead to vocational skills and behavior. Therefore, what must be achieved from the goals of education must be able to realize character education, so that it is clear that education is responsible for the formation of character based on national culture (Kamil P, 2015: 55).

The teacher is the leader in the class. The character of the leader is one of the factors that determine the success and failure of a leader. The success of a leader is based on efforts to make positive habits the material of the leader's character. Teachers have a strategic role for the future of the nation, even the teacher plays the most important role for the advancement of peradap. Because he not only lives for himself, but is a beautiful mirror for hundreds of thousands and even millions of his students who are with him every day (Hendriana \& Jacobus, 2016: 27). On the other hand, the practice of Indonesian education which tends to focus on the development of cognitive aspects and slightly ignores the aspects of soft skills as the main element of character education, makes positive values of education not optimally achieved (Setiawati, 2017: 348).

In the current era of globalization, advances in information and technology, almost everything is global. It is inevitable that the most fundamental resource in modern economics is science. Therefore, economic development in such conditions must be followed by a high enthusiasm for learning in the community accompanied by institutional preparation and cultural context. The development of science alone is not possible if it is not accompanied by readiness of available human resources. Human resources as the main subject in development must prepare some of its members to become science developers. Desired superior human resources are human resources that have high competence. The indicator of having high competence is reflected by having hard skills in the form of specific technical or scientific skills as well as soft skills (Joyoatmojo, 2011: 1-2).

According to Johansyah (2011: 85), among the important issues that are sticking to the surface in the world of education today, especially in Indonesia is character education. This program is a form of response to moral decadence in the building of social reality that has consequences for the deterioration of the nation on various fronts. Even the moral collapse has forced this nation to bend its knees to the values of dehumanization in both structural and cultural circles. In the Indonesian Constitution, Article 31 of the Constitution on Education and Culture in paragraph 3 explicitly states that the government is endeavoring and organizing a national education system that enhances faith and devotion as well as noble character in the context of intellectual life of the nation.

In the Regulation of the Minister of Education and Culture of the Republic of Indonesia Number 20 of 2018, Article 1, it is known that the strengthening of Character Education, hereinafter abbreviated as PPK, is an educational movement under the responsibility of the education unit to strengthen the character of students through harmonizing the process of heart, taste, thought, and sports with the involvement and cooperation of education units, families and communities as part of the National Mental Revolution Movement (GNRM).

Then elaborated in Law Number 20, 2003 concerning the National Education System it is stated that education is a conscious and planned effort to create an atmosphere of learning and learning process so that students actively develop their potential to have religious spiritual strength, self-control, personality, intelligence, noble character, and the skills needed by himself, the community, nation and state. Likewise in the formulation of the National Education Standards mentioned in one of its functions is aimed at ensuring the quality of national education in the context of developing the intellectual life of the nation and shaping the dignified character and civilization of the nation. It is clear that the direction of the goal of conducting education is very noble in its desire to realize a dignified human being who has a noble character (Raharjo, 2010: 230).

Character is a form of character, character, a character inherent in a person's personality that is formed from the results of internalization which is used as a basis for thinking and behaving so as to cause characteristics to the individual. Individual character will develop well, if you get the right reinforcement, namely in the form of education. In connection with the provisions of the Constitution and the Law on National Education System and national education goals that have been set by the government that education in the future must have quality and quality compared to the implementation of education that has taken place today. Therefore, it is necessary to emphasize that Presidential Decree No. 1 of 2010 at every level of education in Indonesia must carry out character education (Citra, 2012: 237).

The world of education is expected to be a driving force to facilitate character building, because what happens in our society actually involves character problems, such as violence, corruption, manipulation, lies and other deviant behavior, departing from education. 
Therefore through education also the character of the nation can be improved and formed especially character building and education starting from an early age. Character development and character education become a necessity because education does not only make students intelligent, it also has character and manners so that its existence as a member of the community becomes meaningful both to himself and others.

According to the Ministry of National Education in (Maimunah, 2015: 91-92), the goals of character education expected by the Ministry of National Education (now: Ministry of Education and Culture) are as follows. First, develop the potential of the hearts / conscience / affective students as humans and citizens who have cultural values and national character. Second, develop students' habits and behavior that are commendable and in line with the universal values and cultural traditions of the nation's religions. Third, instill leadership and responsibility of students as the next generation of the nation. Fourth, develop students' abilities to become independent, creative, national-minded human beings. Fifth, develop the school life environment as a learning environment that is safe, honest, full of creativity and friendship, as well as with a high sense of nationality and full strength (dignity).

Research on educational innovation in character building through innovative media is very important because it has the aim to answer the challenges of globalization today. Today's modern era, it is very necessary innovation in the world of education that integrates with the formation of character. This research itself has been carried out among STKIP PGRI History Education students in Lubuklinggau, semester V. For Historical Education students, innovative learning media is very necessary in learning because besides making it easier to teach it also has its own character values. Students will become increasingly interested in participating in learning and make the learning atmosphere very lively.

Character education that is applied in education in Higher Education, especially in STKIP PGRI Lubuklinggau students is done through group discussion activities. Group discussions are usually carried out during the course of the lecture to discuss material taught by the course's lecturer. The result will be obtained a new learning experience in developing discussion skills for students. Other discussion activities are not only limited to discussions related to the subject matter being discussed, but also discuss social activities in the community. Social activities that are useful for the community are basically noble deeds. This can be explained that this activity is useful in shaping the character of students having a soul of empathy and very high responsibility. Where it really needs to be applied in today's diverse social environment.

\section{METHODS}

The method used in this study is a qualitative description method with research instruments using interview guidelines. This research method is in accordance with the type of research used for case studies, historiography, ethnography, phenomenology, grounded theory, narrative and content analysis (Sugiyono, 2015: 308). In collecting this data, researchers used a sample of research in the fifth semester students of History Education STKIP PGRI Lubuklinggau, amounting to 15 people.

Data collection is then analyzed in various stages, namely: 1) Data reduction which is the process of selecting, focusing attention, abstracting, and transforming data that arises from the results of research; 2) Presentation of data is a collection of structured information that gives the possibility of drawing conclusions and taking action; 3) Conclusion drawing (conclusion drawing) is taken will be handled loosely and remain open so that conclusions that were initially unclear, then will increase to become more detailed and firmly rooted; 4) Data Validity Check which includes: Credibility (credibility), Transferability (Dependability), and dependability, and Confirmability (STKIP PGRI Lubuklinggau, 2015: 46-47).

\section{RESULTS AND DISCUSSION}

\subsection{The Importance Of Character Education}

Utilization of learning resources and media based on students' social environment becomes an alternative to anticipate and overcome these problems. Learning media have an important role in providing new experiences for students in learning and at the same time can assist teachers in delivering messages (subject matter). In addition, teachers can utilize learning resources other than books such as students' everyday social environment so students are accustomed to attitude values (Husni \& Hadi, 2018: 19).

Character education is not just about teaching what is right and what is wrong. More than that, character education instills habits (habituation) about which things are good so that students become aware (cognitive) about what is right and wrong, able to feel (affective) good values and used to do it (psychomotor). In other words, good character education must involve not only the aspects of "good knowledge (moral knowing), but also" feeling well or loving good (moral feeling), and good behavior (moral action). Character education emphasizes the habit or habits that are constantly practiced and carried out. The high character of the people of a nation will bring it to a civilization and progress and peace. If the characteristics / morals of the people are low then a nation is unable to develop itself towards progress and good and respected civilization. Even the lack of character and damage to the character of individuals in society has the potential to cause the destruction of a nation (Johansyah, 2011: 93-94). 
According to Faturohman in (Zulhijrah, 2015: 5), character education is everything that teachers do, which is able to influence the character of students. The teacher helps shape the character of students. This includes exemplary how the teacher behaves, the way the teacher talks or delivers material, how the teacher tolerates, and various other related matters. On the contrary, ethics provides judgments about good and bad, based on the norms prevailing in certain societies, while the morality of the order emphasizes that in essence human beings have embedded beliefs where both (good and bad) exist. Therefore, character education is interpreted as value education, character education, moral education, character education, the purpose of which is to develop students' ability to make good and bad decisions, maintain what is good, and realize that goodness in everyday life with all my heart (Omeri, 2015: 466).

Character education is basically aimed at forming a strong, competitive, noble, moral, tolerant, mutual cooperation, patriotic spirit, dynamic developing, science and technology oriented, all of which are imbued with faith and piety to the One God based on Pancasila. Character education is directed to put pressure on certain values such as respect, responsibility, honesty, caring, and fair and help students to understand, pay attention to, and carry out these values in their own lives to achieve life success (Hendriana \& Jacobus, 2016: 26-27).

In administering the education system one of the important and important elements of education is a teacher. In the implementation of the teaching and learning process the role of the teacher in directing and shaping the situation of student learning largely determines the success of the education. Quality oriented education innovation is a process of managing new resources (ideas, practices, objects, methods) in the field of education to achieve educational goals or solve educational problems. New ideas, practices, objects, and methods that are intended are something that is already running, existing, already practiced in daily management processes within the framework of improving the quality of education (Sofanudin, 2016: 314).

In the era of globalization and the era of very rapid development of science and technology, students are not enough if only equipped with scientific knowledge, they must also be built and fostered their character. Through the education process in schools, students must be prepared to become intelligent people in a comprehensive manner that is intelligent spiritual, intellectual intelligent, emotionally intelligent/social and intelligent kinesthetic, honest, responsible, disciplined, caring, independent, critical and creative, and hard work (Sadia , 2018: 217).

The basic concept of character education is contained in Permendikbud No. 23 concerning the Growth of Character traits in 2015. The development of Character traits (PBP) aims: 1). making the school a fun learning park for students, teachers and education personnel, 2). fostering good habits as a form of character education since in the family, school and community, 3). make education a movement that involves government, regional government, community and family, and / or 4). foster a harmonious learning environment and culture between families, schools and communities (Putri, 2018: 41).

According to the regulation of the President of the Republic of Indonesia Number 87 of 2017 Article 3 contains "PPK implemented by applying the values of Pancasila in character education, especially covering religious values, honesty, tolerance, discipline, hard working, independent, democratic, curiosity, enthusiasm nationality, patriotism, respect for achievement, communicative, peace-loving, fond of reading, caring for the environment, caring socially, and responsible".

Therefore, character education is very much needed in realizing students to have principles of mutual respect and compassion between people. As described above, character education is a holistic educational process that connects the moral dimension with the social realm in the lives of learners as the foundation for the formation of a quality generation that is able to live independently and has the principle of an accountable truth. As for the characters that must be developed are love for God and the universe and its contents, responsibility, discipline and independence, honesty, respect and courtesy, compassion, caring, and cooperation, self-confidence, creative, hard work and unyielding, justice and leadership, kind and humble, and tolerance, peace and unity. The character is instilled into students through the educational process in each subject. This means that character education does not need to stand alone but in each subject contains noble character elements that must be understood and practiced by every student (Raharjo, 2010: 243).

\subsection{Character Education Through Discussion Activities In Stkip Pgri Lubuklinggau Students}

Learning innovation is a teaching and learning process that always presents something new so that it can eliminate boredom and boredom. Innovative learning always presents something new in every element of education starting from the aspects of the teacher's strategy, device materials and several other important elements. The learning process in schools, universities are the core of education at all levels which need to be upgraded. In the learning process, students must gain learning experience to solve the problems faced. Innovative learning is learning that is more student centered. That is, learning provides more opportunities for students/students to construct knowledge independently (self directed) and mediated by peers (peer mediated instruction) (Nugroho, 2019: 75).

Students as a milestone in world development, especially in the field of education. In the world of education, students have a different role than when they were educated in high school. After becoming a student at 
a university students have the task to obtain academic achievements and activities aimed at building their achievements. Students are a hope for the nation. A large and developed nation is built by a bright and global-minded young generation who often produces achievements in building civilization. In addition, in social life, students are called "agents of change" or agents of change for the nation.

In teaching and learning activities, students often do learning by group discussion. The group discussion is carried out to solve a problem that is being discussed. Group discussion was chosen, because it was more effective to produce competent and good ideas. Group discussions are guided by lecturers who are being taught to students. Lecturers as teaching staff have a role in learning as a facilitator in the course of discussion. Structured discussion will produce interesting and lively learning. Although the discussion is a tool in learning, students must keep their egos in order for the discussion to run well.

In Law Number 20 Year 2003 concerning the National Education System it is stated that Pancasila and the 1945 Constitution of the Republic of Indonesia (Article 2), functions to develop capabilities and shape the dignified character and civilization of the nation in order to develop the life of the nation, aiming at developing potential students to be human beings who believe and fear God Almighty, noble, healthy, knowledgeable, capable, creative, independent, and become citizens who are democratic and responsible (Article 3) (Judiani, 2010: 282).

Character education is to engrave morals through the process of knowing the good, loving the good, and acting the good, which is an educational process that involves cognitive, emotional, and physical aspects, so that noble morals can be engraved into a habit of the mind, heart, and hands. Character education is basically aimed at forming a strong, competitive, noble, moral, tolerant, mutual cooperation, patriotic, dynamic, science and technology oriented society, all of which are imbued with faith and piety towards God based on Pancasila (Julaiha, 2014: 229).

Its essential character is a person's character, character, character, or personality that is formed from the internalization of various virtues that are believed and used as a basis for perspective, thinking, acting, and acting. Source of Values (Center for Curriculum Balitbang Kemdiknas): Religion, Pancasila, Culture, National Education Objectives implemented in 18 character values, namely: religious, honest, tolerance, discipline, hard work, creative, independent, democratic, sense of want know, the spirit of nationality, love of the homeland, respect for achievement, friendly/communicative, love peace, love to read, care for the environment, care for the social, responsibility (Adibatin, 2016: 3).

Character education is a process of changing the nature, mentality, character, character of a person or group of people to become adults (whole human being/ human beings). Character education is basically aimed at forming a strong, competitive, noble, moral, tolerant, mutual cooperation, patriotic spirit, dynamic developing, science and technology oriented, all of which are imbued with faith and piety to the One God based on Pancasila. Character education is directed to put pressure on certain values such as respect, responsibility, honesty, caring, and fair and help students to understand, pay attention, and carry out these values in their own lives to achieve life success. Character education in schools can be implemented through exemplary teachers and can also be planted through continual habituation (Hendriana \& Jacobus, 2016: 29).

Character learning strategies are basically ways, patterns, methods, or efforts made by educators (facilitators) by providing facilities so that students are easy to learn, and in the context of character education, the provision of these facilities in a framework for developing good character, or so students can develop their own good character. haracter education has the same essence and meaning as moral education and moral education. The goal is to shape the child's personality, so that he becomes a good human being, a good citizen, a good citizen, and a good citizen of a society or nation, in general are certain social values that are much influenced by the culture of the people and nation. Therefore, the nature of character education in the context of Indonesian education is the education of values, namely the education of noble values that originate from the culture of the Indonesian people themselves, in order to foster the personality of the younger generation.

Instilling value in the School community means that new character education will be effective if not only students, but also Lecturers and the learning environment on Campus where students gain knowledge that must be involved in character education. Character education is the process of planting certain characters as well as member seeds so that students are able to grow their special character when running their lives. Character education rests on basic human characters, which originate from religion which is also referred to as the golden rule. Character education can have definite goals, if it is based on these basic character values (Kurniasih \& Sani, 2017: 76-77).

Related to discussion, it is always associated with the formation of attitudes in learning. The formation of attitudes in learning is related to character education that is developing. Character education itself is education that puts forward activities based on attitude. Sometimes a person has to solve a problem by committing violence, threats, and warfare that harms all parties. The discussion is expected to shape the character of students who are responsible and have a good attitude. Discussion can build good and noble character. Having a good character will add friendship and can achieve the goals we want to achieve. 
In the current era of globalization, a variety of technologies have emerged that make it easier for humans to carry out activities that are useful for themselves and others. Humans must be able to sort out the right technology and not damage the order of human life. Character education can be a filter in facing the current globalization. Not all technologies that emerge today are good for us, but also not all technology today is not good for our lives. Humans must be very clever to see the conditions and situations and adapted to the local wisdom of the Indonesian people. The influence of education in universities is very important in developing the nation's character that is virtuous and competent.

Indonesian local wisdom is a society that loves peace and upholds noble values. The values of local wisdom must be upheld and preserved by the local community. This local wisdom can be in the form of culture, language, community activities and others that are useful for the community. When the emergence of technology from the swift globalization, the local wisdom of Indonesian people sometimes affected and began to be left behind for today's young generation. So the current need for character education for young people today. Character education integrated with local wisdom can help the development of good learning in the family, school and community environment. The current millennial era requires young people who are competent, intelligent, global in mind, and have a supportive character for the Indonesian people. Times are indeed modern, but humans must have good character without having to leave local wisdom.

The development of character education more specifically must also pay attention to the educational environment. More importantly, that the teacher as an educator must have a high personality so that he deserves to be exemplified. Another step that can be taken is to reproduce religious nuances in schools, where this does not have to be included in the curriculum (Johansyah, 2011: 99).

Character education taught in discussions not only occurs in the classroom learning environment, but also other social activities. Social activities such as social service, opening together with orphans, cleaning trash on the streets, and other social activities that are useful for the nation and country. The role of youth and students in welcoming the era of globalization is indeed very important, but youth must have good character in the midst of a pluralistic society. The attitude of the character formed must build and can have a positive impact on the progress of a country. Developing and developing countries are built by the roles of smart, bright young people, without leaving their national character. The character education of a nation must coincide with the state of the country which is receiving technological advancements.

Character education is something that cannot be underestimated. Various immoral cases that hit this country especially the perpetrators came from among the students indicated that this nation is suffering from a crisis of character. If this is not resolved immediately, then the future and the fate of the nation and our children and grandchildren will eventually bear all the consequences. For this reason, so that the expectations of the implementation of character education can be realized, namely the creation of a generation of noble character, it is necessary to carry out effective character education as described in the previous discussion (Purnomo, 2014: 83).

The character education process in the STKIP PGRI Lubuklinggau History Education Study Program is carried out in an integrated manner. The process is based that so far there is a belief that children will grow up well if naturally involved in the learning process. The term integrated in learning means that learning emphasizes learning experiences in a meaningful context. Integrated teaching can be defined: a concept in a learning approach that involves several fields of study to provide meaningful experiences for students. Said to be meaningful because in integrated learning, students will understand the concepts learned through direct experience and relate them to other concepts that have been understood through the opportunity to learn what relates to authentic themes or events (Samrin, 2016: 138).

\section{CONCLUSION}

Discussions are activities that build character for current students. Learning will come alive if the implementation of the discussion model is well implemented. Discussion basically can build two-way or more communication for students with the guidance of the Lecturer Supervising the Subject. Not only limited to discussions on the subjects studied, but also related to discussions related to social activities that are being undertaken. Character education for STKIP PGRI Lubuklinggau students is very important and needs to be preserved. The discussion will add valuable experience for students how to shape character in life within the campus and the community.

\section{REFERENCES}

Adibatin, Ani, (2016). Nation Character Education Based on Pakem's Learning Strategies Through the Ring Game in the Thumbs (Elementary School Learning Innovation Works). Scholaria. 6 (1): 3.

Citra, Yulia, (2012). Implementation of Character Education in Learning. E-JUPEKhu (Journal Special Scientific Education). 1 (1): 237.

Hendriana, Evinna Cinda \& Jacobus, Arnold, (2016). Implementation of Character Education in Schools Through Exemplary and Habitual. Indonesian Basic Education Journal. 1 (2): 26-27.

Hidayatullah, et al, (2017). Innovative Learning to Embed Character Values in Elementary School Students (Meta-Synthesis Study). Proceedings of the National Seminar on Indonesian Educators and Educational Developers with the theme "Building 
Character Generation through Innovative.

Husni, Muhammad \& Hadi, Yul Alfian Hadi, (2018). Development of Audio Learning Media Visual Pkn Based on Value Clarification Techniques in Dasardi School Students in East Lombok Regency. DIDIKA Journal: Forum for Scientific Basic Education. V (2): 19.

Jalil, (2012). Character Education to Shape Character Education. Nadwa | Journal entry Islamic education. 6 (2): 176.

Johansyah, (2011). Character Education in Islam; Study of Methodological Aspects. Futura Islamic Scientific Journal. XI (1): 86-103.

Joyoatmojo, Soetarno, (2011). Effective Learning Effective Learning. UNS Press, Surakarta.

Judiani, Sri, (2010). Implementation of Character Education in Primary Schools Through Strengthening Implementation of the curriculum. Journal of Education and Culture. 16 (III): 282.

Julaiha, Siti, (2014). Implementation of Character Education in Learning. The Dynamics of Science. 14 (2): 229.

Kamil P, (2015). Character Building Through Sociology Education. The window. XI (1): 55.

Kurniasih, Imas \& Sani, Berlin, (2017). Character Internalization Education and Methods Learning in Schools. Said Pena, Jakarta.

Maimunah, (2015). Implementation of Character Education in Personality Formation Holistic Students. Journal of Character Education, V (1): 91-92.

Nugroho, Rahmat Joko, (2019). Character-Based Learning Innovation in the Industrial Age 4.0. Ejournal, Cakrawla: Management Studies in Islamic Education and Social Studies. 3 (1): 75.

Omeri, Nopan, (2015). The Importance of Character Education in the World of Education. Education Manager. 9 (3): 466.

Prasetya, (2017). Development of Multimedia Learning in Education for Love Characters Tear PKN Lessons. E-Journal of Educational Technology Study Program. VI (1): 56.

Purnomo, Sutrimo, (2014). Character Education in Indonesia: Between Asa and Reality. Journal entry Education. II (2): 83.

Putri, Dini Palupi, (2018). Character Education in Primary School Children in the Digital Age. AR-RIAYAH: Journal of Basic Education. 2 (1): 41.

Raharjo, Sabar Budi, (2010). Character Education as an Effort to Create Morals Noble. Journal of Education and Culture, 16 (3): 229-238.

Sadia, I Wayan, et al, (2018). The Integrated Character Learning Model for Science Learning. Indonesian Education Journal. 2 (2): 217.
Samrin, (2016). Character Education (A Value Approach). Al-Ta'dib Journal. 9 (1): 138.

Setiawati, Nanda Ayu, (2017). Character Education as a Pillar of Character Building Nation. Proceedings of the Annual National Seminar of the Faculty of Social Sciences, Medan State University. 1 (1) (2017): 348.

Sofanudin, Aji, (2016). Management of Quality-Oriented Education Innovation in $\mathrm{Mi}$ Wahid Hasyim Yogyakarta. Scholar. 14 (2): 314.

STKIP PGRI Lubuk, (2015). Thesis Writing Guidebook. Lubuklinggau: STKIP PGRI.

Sugiyono, (2015). Educational Research Methods Quantitative, Qualitative and R\&D Approaches. Bandung: Alfabeta.

Wiliandani, Angga Meifa, et al, (2016). Implementation of Character Education in Learning at Elementary School. Journal of Humanities Education. 4 (2): 133.

Zulhijrah, (2015). Implementation of Character Education in Schools. Adrib. 1 (1): 5. 